\title{
先天性消化管閉塞症を合併した先天性心疾患の検討
}

\author{
平野 恭悠 ${ }^{1,2)}$, 江原 英治 ${ }^{2)}$, 村上 洋介 ${ }^{2)}$, 中村 香絵 ${ }^{2)}$, 佐々木 赳 ${ }^{2)}$, \\ 藤野 光洋 ${ }^{2)}$, 川崎 有希 ${ }^{2)}$, 西垣 恭一 ${ }^{3}$, 吉田 葉子 ${ }^{4)}$, 鈴木 嗣敏 ${ }^{4)}$ \\ 1) 大阪母子医療センター小监循環器科 \\ 2) 大阪市立総合医療センター小児医療センター小紧循環器内科 \\ 3) 大阪市立総合医療センター小児医療センター小児心臓血管外科 \\ 4) 大阪市立総合医療センター小児医療センター小児不整脈科
}

\section{Clinical Features of Congenital Heart Disease Accompanied by Congenital Intestinal Atresia}

\author{
Yasuhiro Hirano, ${ }^{1,2)}$, Eiji Ehara ${ }^{2)}$, Yosuke Murakami ${ }^{2}$, Kae Nakamura $^{2)}$, Takeshi Sasaki²), \\ Mitsuhiro Fujino ${ }^{2)}$, Yuki Kawasaki ${ }^{2)}$, Kyoichi Nishigaki ${ }^{3)}$, Yoko Yoshida ${ }^{4}$, and Tsugutoshi Suzuki ${ }^{4}$ \\ ${ }^{1)}$ Department of Pediatric Cardiology, Osaka Women's and Children's Hospital, Osaka, Japan \\ ${ }^{2)}$ Department of Pediatric Cardiology, Osaka City General Hospital, Osaka, Japan \\ ${ }^{3)}$ Department of Pediatric Cardiovascular Surgery Osaka City General Hospital, Osaka, Japan \\ 4) Pediatric Electrophysiology, Osaka City General Hospital, Osaka, Japan
}

Background: Individualized approach is the key for the successful management of congenital heart disease (CHD) complicated by congenital intestinal atresia (CIA). There are few reports for diagnosing, outcomes and prognostic factors in these patients.

Methods: Medical records of 61 patients (40 males and 21 females; median gestational week, 38; median birth weight $2.5 \mathrm{~kg}$ ) with CHD and CIA treated between 1994 and 2011 were retrospectively evaluated. Patients with both CHD and CIA were evaluated by a subgroup of CIA.

Results: CHD diagnoses included ventricular septal defect $(n=22)$, patent ductus arteriosus $(n=8)$, tetralogy of Fallot $(n=7)$, and atrial septal defect $(n=5)$. CIA included anal atresia $(n=31)$, esophageal atresia $(n=17)$, duodenal atresia/stenosis $(n=10)$, and Hirschsprung's disease $(n=10)$. The overall survival rate of patients was $83 \%$. Thirty-one had chromosomal abnormalities. Of those, 7 patients died. Forty patients received surgeries for both CHD and CIA consequently. In 1 patient with anal atresia, the site of stoma influenced cardiac operation. One patient with esophageal atresia underwent CIA operation after cardiac palliation for high pulmonary blood flow. One patient had duodenal obstruction associated with suture failure for high pulmonary blood flow. Three patients with Down syndrome that underwent proctostomy for Hirschsprung's disease died from fulminant enteritis.

Conclusions: Our individualized approaches provided a high survival rate in neonates with CHD and CIA. Our strategy included CIA operation preceded CHD operation. The high pulmonary flow needed prompt intervention to prevent circulation failure and suture failure. Down syndrome patients undergoing proctostomy should be carefully monitored for post-surgical fulminant gastroenteritis.

Keywords: chromosomal abnormality, congenital heart disease, congenital intestinal atresia

背景 : 先天性心疾患に先天性消化管閉塞症を合併する場合には, 個々の症例に応じた治療戦略が求め られる. しかし，両者を合併した症例の治療成績，予後に関する報告は少ない。

対象と方法：1994〜2011 年に当院で治療を行った先天性消化管閉塞症を合併した先天性心疾患 61 例

2019 年 12 月 25 日受付, 2021 年 3 月 2 日受理

著者連絡先：７594-1101 大阪府和泉市室堂町 840 大阪母子医療センター小児循環器科＼cjkstart平野恭悠

doi: $10.9794 /$ jspccs.37.117

(C) 2021 Japanese Society of Pediatric Cardiology and Cardiac Surgery 
を対象とし, 診断, 治療経過, 予後を後方視的に検討した. 消化管閉塞症と心疾患ともに手術介入し た症例については消化管疾患毎のサブグループに分けて治療経過，問題点を検討した.

結果：心疾患は心室中隔欠損 22 例, 動脈管開存 8 例, Fallot 四徵 7 例, 心房中隔欠損 5 例, 大動脈縮 窄，肺動脈閉鎖兼心室中隔欠損，両大血管右室起始が各 3 例，完全型房室中隔欠損，単心室，総肺静 脈還流異常が各 2 例, その他 4 例であった. 合併消化管閉塞症は, 鎖肛 31 例, 食道閉鎖 17 例, 十二 指腸閉鎖・狭窄 10 例, Hirschsprung 病 10 例であった. 予後は生存 51/61 例（83\%）であった. 染色 体異常・奇形症候群が半数あり, 死亡例では $70 \%$ を占めた。 心疾患, 消化管閉塞症ともに手術したも のが 40 例で, うち 38 例は心臓手術より消化器手術を先行することで概ね経過良好であった. しかし, 鎖肛の 1 例で人工肍門の位置が心臓手術に影響した。食道閉鎖で肺血流増加のため 1 例心臟手術を先 行し，十二指腸閉鎖・狭窄で 1 例消化管術後に肺血流増加で縫合不全を合併した. Down 症候群に伴 う Hirschsprung 病の 3 例が劇症型腸炎で急変, 死亡した。

結論：消化管閉塞症を合併した先天性心疾患において, 基本的に消化管から介入し, 次に心疾患に介 入する方針で生存率 $83 \%$ の結果が得られた. 肺血流増加型の心疾患は循環動態のコントロールが付か ない例や創傷治癒に影響する例があり, 迅速な対応が必要である. Down 症候群の Hirschsprung 病, 人工肛門造設例における劇症型腸炎は致死的となりうるため, 注意が必要である.

\section{背 景}

近年，先天性心疾患の診断および治療技術は急速に 進歩し, かつては救命困難と考えられていた複合心奇 形が救命されるようになった．また，小児外科疾患 も, 出生前または出生後まもなく診断されるととも に, 周産期医療の進歩により, 治療成績が向上してい る.

一方, 先天性消化管閉塞症と先天性心疾患の両者を 合併した例においては, 個々の症例に応じた治療戦略 が求められる. また両者の合併例では, 染色体異常や 低出生体重児の割合が高く, 予後に影響する. しか し，このような消化管閉塞症合併例の先天性心疾患の 治療成績, 予後に関する報告は少ない, 今回, 当院で の先天性消化管閉塞症を合併した先天性心疾患の診 断, 治療経過, 予後を検討し, 管理上の問題点につい て考察した.

\section{対象と方法}

対象は 1994〜2011 年に, 当院で治療を行った先天 性消化管閉塞症（食道閉鎖症，十二指腸閉鎖・狭窄， Hirschsprung 病, 鎖肛) を合併した先天性心疾患 61 例（男 40 例，女 21 例）であった。在胎週数は $31 〜$ 41 週 (中央值 38 週), 出生体重は $1.4 \sim 3.8 \mathrm{~kg}$ (中央 值 $2.5 \mathrm{~kg}$ ）で, 院内出生は 10 例（16\%）であった。 診療録より, 診断, 治療経過, 予後を後方視的に検討 した. 先天性消化管閉塞症と先天性心疾患ともに手術 介入した症例については消化管疾患毎のサブグループ に分けて治療経過を検討した。 なお, 致死的疾患であ る 18 trisomy, Potter 症候群は対象から除外した. 本
研究は患者あるいはその代諾者からインフォームドコ ンセントを得て, また当院倫理委員会の承認のもと 行った（倫理委員会承認番号：2012133）.

\section{結＼cjkstart果}

\section{心疾患の主診断 (Fig. 1)}

心疾患の主診断は心室中隔欠損 22 例, 動脈管開存 8 例, Fallot 四徵 7 例, 心房中隔欠損 5 例, 大動脈縮 窄, 肺動脈閉鎖兼心室中隔欠損, 両大血管右室起始が 各 3 例, 完全型房室中隔欠損, 単心室, 総肺静脈還流 異常が各 2 例, 僧帽弁閉鎖, 左心低形成症候群，完全 大血管転位, 肺動脈狭窄が各 1 例であった. 61 例中 43 例 (70\%) が心疾患に対する治療介入を必要とし その内訳は, 外科手術 40 例, カテーテル治療 3 例で あった．カテーテル治療の内訳は肺動脈狭窄に対する バルーン拡大, 大動脈縮窄に対するバルーン拡大, 動 脈管に対するコイル塞栓術が各 1 例であった.

\section{合併消化管疾患}

合併消化管疾患は鎖肛 31 例（51\%)，食道閉鎖 17 例 (28\%), 十二指腸閉鎖・狭窄 10 例（16\%), Hirschsprung 病 10 例 (16\%) であった（重複あり）. 本院への紹介前に前医で消化管疾患の手術を受けてい た例が 9 例あった.

\section{消化管疾患の胎児診断 (Fig. 2)}

消化管疾患の胎児診断は，食道閉鎖 5/17 例 $(29 \%)$ ，鎖肛 $2 / 31$ 例（6\%)，十二指腸閉鎖・狭窄 6/10 例 (60\%), Hirschsprung 病 0/10 例 (0\%) でさ れていた (61例 68 疾患). 院内出生が 10/61 例 (16\%) 

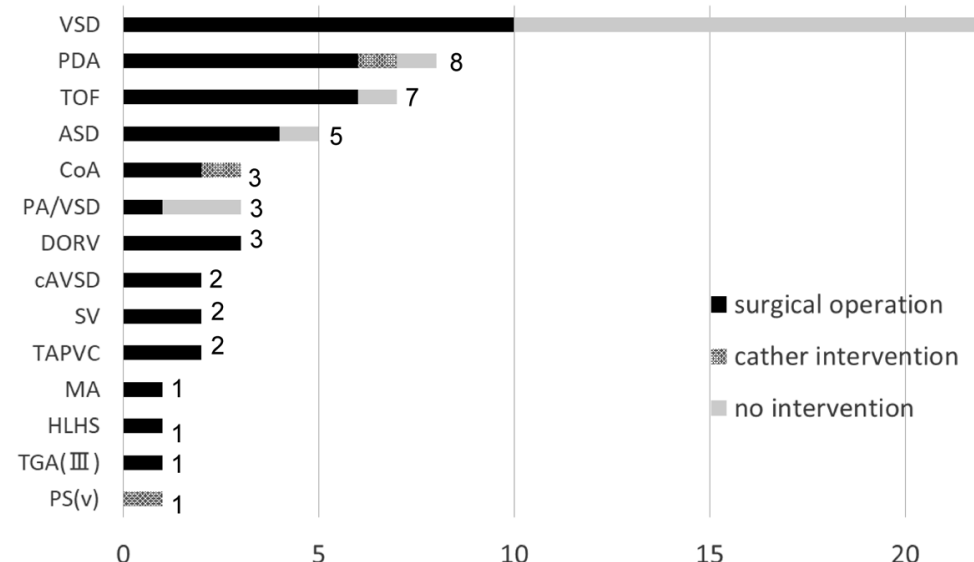

Fig. 1 Main diagnosis of heart disease $(N=61)$

ASD, atrial septal defect; cAVSD, complete atrioventricular septal defect; CoA, coarctation of the aorta; DORV, double outlet right ventricle; HLHS, hypoplastic left heart syndrome; MA, mitral atresia; PA, pulmonary atresia; PDA, patent ductus arteriosus; PS(v), valvular pulmonary stenosis; SV, single ventricle; TAPVC, total anomalous pulmonary venous connection; TGA, transposition of the great arteries; TOF, tetralogy of Fallot; VSD, ventricular septal defect.

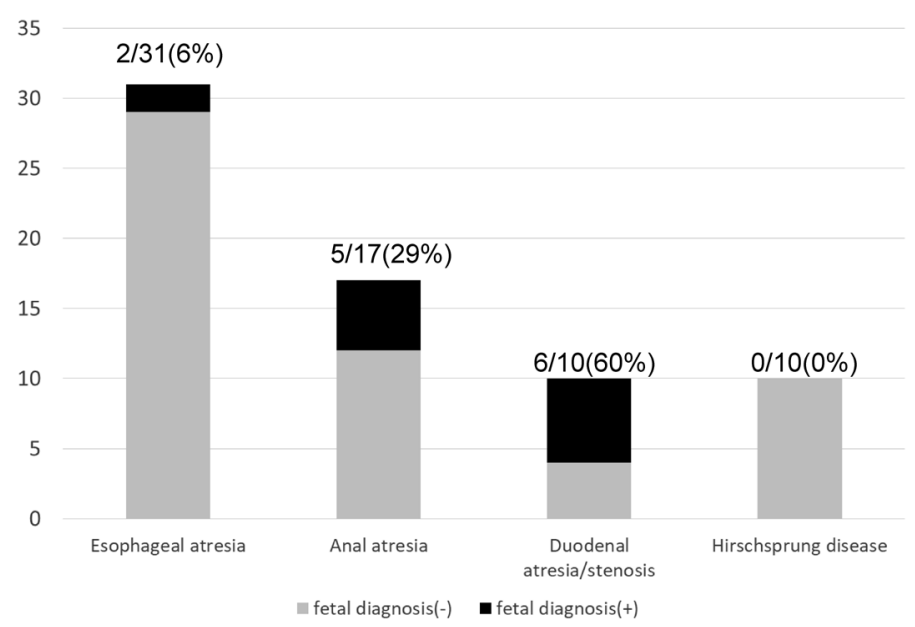

Fig. 2 Fetal diagnosis of congenital intestinal atresia

であった背景もあるが，十二指腸閉鎖・狭窄を除いて 胎児診断例は少なく, 診断率は全体で 13/61 例 (21\%) であった。しかし，院内出生に限ると $8 / 10$ 例 $(80 \%)$ であった。また心疾患の胎児診断率は, 5/61 例（8\%） であった．院内出生に限っても $3 / 10$ 例（30\%）と診 断率は高くなかった.

\section{染色体異常・奇形症候群}

染色体異常等の全身性合併症を伴うものが 31/61 例（51\%）あった。 その内訳は Down 症候群 15 例, VATER 連合 5 例, CHARGE 症候群 3 例で, 22 trisomy 2 例，その他 46XYdel（11）（q23.3），47XY+ mar, 9p-, Kabuki 症候群, Treacher-Collins 症候群, Coffin Siris 症候群が各 1 例であった.

\section{手術と治療経過}

心疾患の初回手術時期は, 日齢 $1 \sim 5$ 歳（中央值 3 か月）で新生児期は 18 例であった。消化管疾患の 初回手術時期は日齢 0 2 歳（中央值 2 日）であっ た. 心疾患，消化管疾患ともに手術したものが 40 例 （66\%）でその治療経過を Fig. 3 に示す.内訳は 1) 消化管姑息手術 $\rightarrow$ 心藏手術 $\rightarrow$ 消化管根治術の順であつ たものが 13 例，2）消化管根治術 $\rightarrow$ 心臓手術が 25 例，3）心臓手術 $\rightarrow$ 消化管根治術が 2 例であった. 38 例は消化管疾患の手術を先行し，その後心臓手術を 行っていた.

ここから, 消化管閉塞症と先天性心疾患ともに手 術を行なった 40 症例に関して消化管閉鎖症の疾患別 にサブグループ（食道閉鎖，十二指腸閉鎖・狭窄， 


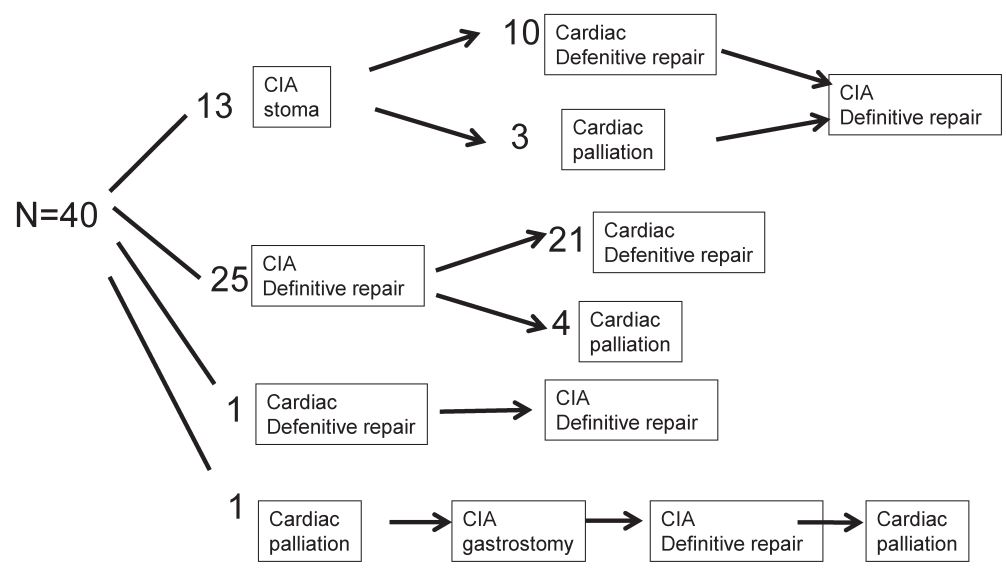

Fig. 3 Operation of congenital heart defect and congenital intestinal atresia $\mathrm{CIA}$, congenital intestinal atresia.

(a) Esophageal atresia $(\mathrm{N}=17)$
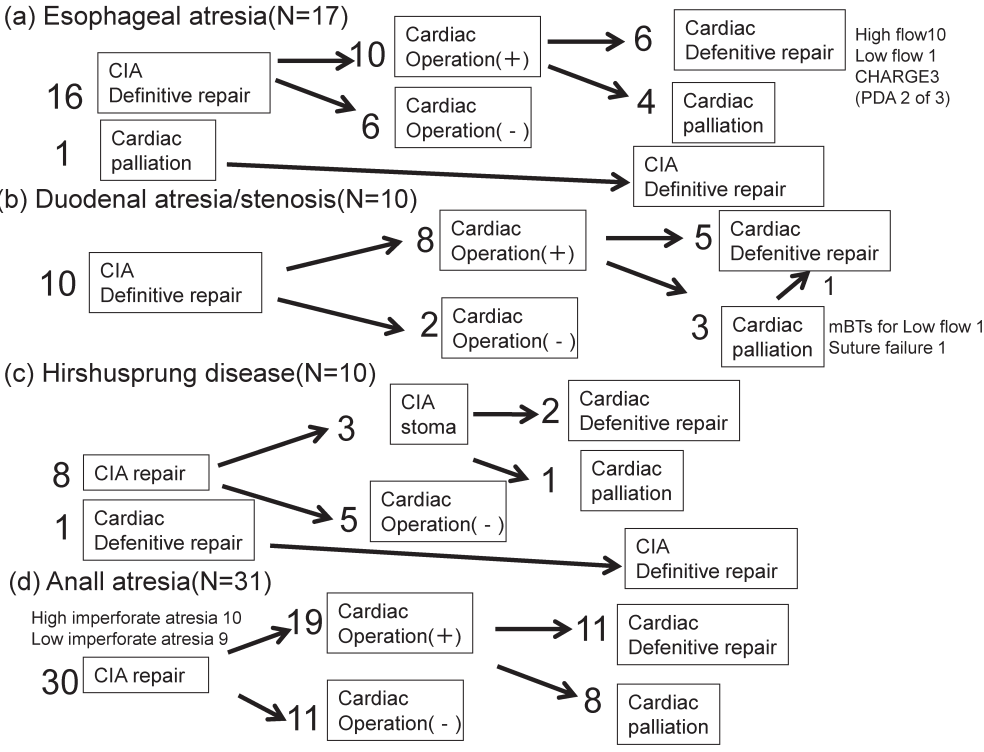

Fig. 4 Subgroup analysis

$\mathrm{CIA}$, congenital intestinal atresia; mBTs, modified Blalock-Taussig shunt.

Hirschsprung 病, 鎖肛）に分けて検討する（Fig. 4). 食道閉鎖は 17 例中 11 例で, 消化管と先天性心疾 患ともに手術を行っていた。 全例 C 型（下側の食道 が気道につながっている）であり Long-gap 症例はな かった. 肺血流減少の心疾患は 1 例あり, Fallot四 徵のために生後 1 か月時に修正 Blalock-Taussig 短絡 術（BT シャント術）が必要であったが, 消化管の創 傷治癒に影響なく，感染性心内膜炎を呈することもな かった．肺血流増加の疾患が 10 例あったが，消化管 手術後の経過は良好で経腸栄養が確立し，心臓手術を 施行できた. CHARGE 症候群が 3 例あり，うち 2 例 の心疾患は動脈管開存症でともに新生児期に結禁術を 施行した．胎児診断の 1 例で，当初の治療予定を関
係診療科で見直す対応が必要となった。 心疾患は大動 脈縮窄，両大血管右室起始，左室低形成で，院内出生 で消化管疾患，心疾患ともに胎児診断されていた。食 道閉鎖と大動脈縮窄の同時手術はリスクが高いため, 当初は食道閉鎖の手術後，状態が安定したところで大 動脈縮窄の修復術を計画していた. しかし, 出生後 2 時間で呼吸不全のため人工呼吸管理を要するとともに 気管食道瘦のため腹部膨満が増強した。さらには，プ ロスタグランジン $\mathrm{E}_{1}$ 製剤の持続静注により，高肺血 流による心不全が増悪，窒素ガス吸入による低酸素換 気療法が必要となった。そのため，小児循環器，小児 心臓外科，小児外科と協議のうえ日齢 1 に緊急避難的 に両側肺動脈絞扼術と胃瘻増設を施行した。状態の安 
定を待って日齢 3 に食道閉鎖根治術を行い, 日齢 22 にバルーン心房中隔裂開術, 経腸栄養が確立した日齢 26 に大動脈縮窄修復術を施行した. しかしその後心 臓カテーテル検査後の原因不明の低血糖のため重度の 脳障害となりフォンタン手術まで到達できていない. 肺血流増加型の心疾患 10 例のうち, CHARGE 症候 群の 3 例以外の 7 例は食道閉鎖の術後経過は良好で 問題なく心疾患の管理ができた. その 7 例のなかで 1 例は Down 症候群を合併した単心室の症例で, 日齢 1 に食道閉鎖根治術を施行し術後経過は良好で 2 歳で Fontan 手術に到達した.

十二指腸閉鎖 - 狭窄は 10 例中 8 例で, 消化管と先 天性心疾患ともに手術を行っていた。 全例で日齢 10 日以内に消化管手術を施行して概ね安定した状態で心 疾患の手術を施行できた. 完全大血管転位 III 型の 1 例で BT シャント術を施行したが, BT シャント術は 消化管手術後の経過が落ち着き栄養の確立した生後 4 か月であった. そのため, BT シャント術の肺血流増 加による消化管の術後への影響はなかった. 一方心室 中隔欠損症, 大動脈縮窄症, Down 症候群の 1 例で, 日齢 2 に消化管手術を施行したが, 日齢 7 に高肺血 流のため腸管の縫合不全を合併し, 状態が安定せず $2,100 \mathrm{~g}$ と低出生体重児であり, 日齢 9 に両側肺動脈 絞扼術を施行した. その後, 循環動態が安定し栄養を 確立することができた. 生後 1 か月で大動脈縮窄修復 術と心内修復術を実施した。

Hirschsprung 病は 10 例中 4 例で, 消化管と先天性 心疾患ともに手術を行っていた. 3 例が人工肚門を造 設後, 心蔵手術を施行していた. 1 例は人工肛門を必 要せず, 消化管の状態が安定しており心室中隔欠損症
と右室二腔症の心内修復術後に, 消化管の根治術を施 行していた。なお， 2 例が人工肛門を造設した Down 症候群で, 劇症型腸炎による急激な脱水を契機とした 末梢循環不全のため急変, 死亡した.

鎖肛（31 例中 19 例）に関しては，概ね消化管手術 後の経過は良好で経腸栄養が確立し, 心蔵手術を施行 できた. 高位鎖肛（10 例）は, 人工肛門を日齢 1 6 (中央值 1) に造設し, 8 か月 2 歳 8 か月（中央值 1 歳 5 か月）で消化管根治術を施行していた。 また心 疾患に対しては 3 例に姑息術を日齢 3 8 か月, 7 例に 心内修復術を日齢 $48 \sim 2$ 歳 8 か月 (中央值 1 歳 4 か月) に施行していた。低位鎖肚（9例）では，日齢 0 1 (中央值 1）に初回手術で消化管根治手術を施行し, 心疾患の姑息術を 5 例で日齢 1 10 か月（中央值 2 か 月）に，4例で心内修復術を 2 か月～1 歳 7 か月（中 央值 5 か月）に施行していた. BT シャント術を施行 した Fallot 四徴症の症例が 3 例あったが，消化管術後 の創傷治癒に影響することはなかった。 ただ 1 例で人 工肛門の位置が心臓手術に影響し, 当初の治療予定を 多科で見直す対応が必要であった。在胎 36 週 6 日, 出生体重 $2,805 \mathrm{~g}$ で出生した. 診断は両大血管右室起 始, 肺動脈弁狭窄, 中位鎖肛, Kabuki 症候群であっ た. 日齢 1 に会陰式肛門形成術を施行したが, 術後イ レウスのため横行結腸人工肛門造設術を施行した。さ らに術後腹腔内腸管穿孔のため, 人工肍門はやむをえ ず胸部近くの上腹部に造設した. その後, 肺血流増多 による心不全症状が出現しその時点では, 正中切開を 要する心内修復は感染のリスクが高いと判断し, 生後 2 か月でいったん左開胸で肺動脈絞扼術を施行し, 体 重増加を待って1歳3か月時に心内修復術を施行した.

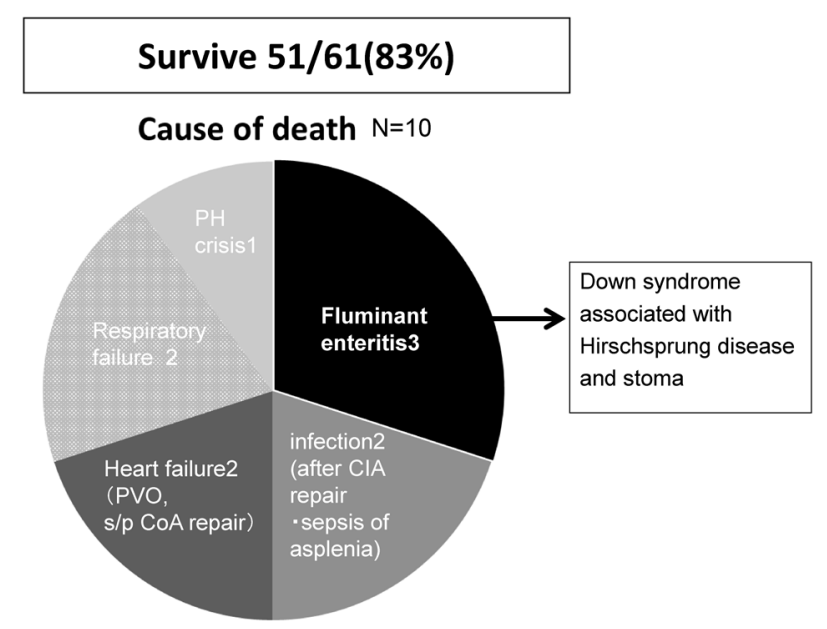

Fig. 5 Prognosis

$\mathrm{CIA}$, congenital intestinal atresia; CoA, coarctation of the aorta; $\mathrm{PH}$, pulmonary hypertention; PVO, pulmonary vein obstruction. 
Table 1 Three patients of fulminant enteritis with Hirschsprung disease and Down syndrome

\begin{tabular}{|c|c|c|c|c|c|c|}
\hline & Age & Heart disease & QpOs & $\begin{array}{l}\text { Time from the onset } \\
\text { of colitis to death }\end{array}$ & $\begin{array}{l}\text { WBC } \\
(/ \mu \mathrm{L})\end{array}$ & $\begin{array}{c}\mathrm{CRP} \\
(\mathrm{mg} / \mathrm{dL})\end{array}$ \\
\hline 1 & $11 \mathrm{~m}$ & VSD & 3.07 & $20 \mathrm{hr}$ & 26,500 & 0.0 \\
\hline 2 & $1 \mathrm{y} 1 \mathrm{~m}$ & s/p VSD closure & 1.05 & $12 \mathrm{hr}$ & 16,900 & 1.56 \\
\hline 3 & $1 \mathrm{y} 11 \mathrm{~m}$ & cAVSD, hypoplastic RV, s/pPAB & 1.21 & $10 \mathrm{hr}$ & 5,000 & 11.15 \\
\hline
\end{tabular}

CAVSD, complete atrioventricular septal defect; PAB, pulmonary artery banding; VSD, ventricular septal defect.

\section{予後（Fig. 5)}

全体の生存率は $51 / 61$ 例（83\%）であった. 死亡 10 例の死因は劇症型腸炎による脱水 3 例, 感染 2 例, 心不全 2 例, 呼吸不全 2 例, 肺高血圧クリーゼ 1 例 であった．染色体異常は 61 例中 31 例 $(51 \%)$ であっ たが，死亡例 10 例の中では 7 例（70\%）であった. 消化管疾患が死因となったのは 4 例で, うち 3 例は Hirschsprung 病で人工肛門を造設した Down 症候群 で，死因は劇症型腸炎による急激な脱水を契機とした 末梢循環不全であった（Table 1). 3 例とも胃腸炎発 症から 10〜20 時間以内に死亡するという非常に急激 な経過を辿っていた，消化管疾患が死因となった 4 例 の残り 1 例は食道閉鎖術後の敗血症であった.

\section{考察}

今回我々は, 当施設での先天性消化管閉塞症を合併 した心疾患の治療経過, 予後を検討したが, 関係診療 科の連携のもと個々の症例に応じた治療計画を立てる ことで生存率 $83 \%$ であった. 基本は消化管の手術を 先行して, 心疾患の手術を施行することで, 従来の報 告と同様の良好な結果が得られた。 また, 染色体異 常・奇形症候群が半数あり死亡例の $70 \%$ を占めてい た.川田らは, 食道閉鎖, 鎖肚などの消化管病変を合 併した心疾患 75 例のうち死亡例は 10 例と報告して いる ${ }^{1)}$. また, 遠隔予後を規定するのは, 多くの場合 心疾患そのものの重症度と考察している. Walker ら は，新生児の消化管手術を施行した 18 例の心疾患を 対象とした検討を行い，死亡例は 2 例と報告している (左心低形成症候群と総動脈幹症, ともに死因は心不 全） ${ }^{2)}$ 。また，新生児死亡の原因に占める心疾患の割 合は鎖肚では $72.7 \%$, 食道閉鎖では $10 \%$ を占めると いう報告がある ${ }^{3)}$. 今回の我々の検討では, 予後に関 しては従来の報告とほぼ同様の成績であり, 消化管疾 患が死因となったのは 4 例のみであった。一方, 今回 の検討で死亡例 10 例のうち 7 例 (70\%) が染色体異 常・奇形症候群を合併例であった。予後については, 心疾患そのものよりも染色体異常 - 奇形症候群の存在
の関与が大きいと推察された.

食道閉鎖は, VATER 症候群として多発奇形を合併 することが多い. Spitzらは重症心奇形の合併のみが 食道閉鎖の独立した予後不良因子になるとして新しい リスク分類を提唱している ${ }^{4)}$. 食道閉鎖の問題点とし て陽圧換気による腹部膨満と消化液の逆流による䛊嚥 がある. 胃食道逆流や気管食道瘦に起因する反復性 誤興により生じる低酸素性肺血管攣縮は単独で高度の 肺高血圧を生じ得ると村上らは述べている ${ }^{5)}$. 特に,

Fontan 手術を目指す心疾患で食道閉鎖を合併する症例 では，早期に食道閉鎖の手術を施行し，慢性肺障害を 防ぐ必要があるとしている. また, Long-gap で一期的 に食道を吻合できない症例や染色体異常・奇形症候群 など，與下障害を伴う症例でも誤與に起因する肺障害 のため右心バイパス術を困難にする要因となる。さら に，食道閉鎖は開胸での消化管手術で不潔操作となる ので，人工血管を用いる心臓手術を回避したいが，必 要な時は, 感染性心内膜炎への注意を払うべきである.

今回消化管疾患・ 心疾患とも緊急性を要した症例が 1 例あった. C 型食道閉鎖, 大動脈縮窄, 両大血管右 室起始, 左室低形成, CHARGE 症候群の例で, 出生 後, 肺血流増多のために日齢 1 に緊急的に両側肺動脈 絞扼術を施行し, 循環動態を安定させたうえで日齢 3 に食道閉鎖根治術を行った。 その後, 日齢 26 に大動 脈縮窄修復術を施行した。この症例は，食道閉鎖根治 術前に肺血流量適正化のための心臓手術が必要であっ た．麻生らは，胎児診断された症例で 24 時間以内の 超緊急手術例が多く施行できるようになっており, 出 生前より消化管疾患 - 心疾患に対して個々の症例に応 じた介入を計画し，準備できるので，出生前診断は有 用であると報告している ${ }^{6)}$. しかし今回の検討では， 消化管疾患の胎児診断例が 13/61 例（21\%）と未だに 少なく, 改善が必要である.

十二指腸閉鎖・狭窄疾患に関して，1 例で新生児期 に心室中隔欠損症・大動脈縮窄症の高肺血流による縫 合不全があり両側肺動脈絞扼術を施行した症例があっ た.なお, BT シャント術後に十二指腸手術後の創傷 治癒に影響した症例はなかった。肺血流を動脈管に依 
存する例や BT シャント術後例で, 特に高肺血流に傾 く症例では拡張期血圧が低下し腸管血流が低下する。 そのような病態では，消化管手術後の創傷治癒に影響 し壊死性腸炎やイレウス, 縫合不全などの合併症への 注意が必要である.

村上らは, 上腹部の人工肚門の存在は胸骨正中切 開後の縦隔洞炎のリスクを高めると述べている ${ }^{5)}$. 今 回, 我々が経験した人工肛門の位置が心臟手術に影響 した両大血管右室起始・肺動脈弁狭窄・中位鎖肛の症 例は, 消化管疾患の緊急性のため, 人工肛門を正中近 くに造設せざるをえなかった. 正中切開を要する心内 修復では感染のリスクが高く, いったん左開胸で肺動 脈絞扼術を施行し, 体重増加を待ち鎖肛根治術, 人工 肛門閉鎖後に心内修復術を行った. 高位鎖肚で人工肛 門を造設後に開心術を行う場合には人工肛門造設の位 置を通常より下方もしくは正中より遠ざける工夫が必 要と考えられた。

消化管疾患が死因となった症例は 4 例あった. 特筆すべき点は, うち 3 例は急性胃腸炎で, 全例 Hirschsprung 病で人工肛門を造設した Down 症候群 であったことである.いずれも胃腸炎発症から 10〜 20 時間以内に死亡するという劇症型の経過を辿って いた．死因は劇症型腸炎による急激な脱水を契機とし た末梢循環不全であった。池田らは, Hirschsprung 病 に Down 症候群と心奇形を同時に合併すると死亡率 が $38.1 \%$ と高率になると報告している ${ }^{7)}$. Teitelbaum らは, 80 人の Hirschsprung 病の患児を対象とし, 腸炎の合併率について Down 症候群 13 例と非 Down 症候群 67 例とで比較し, Down 症候群は 46\%, 非 Down 症候群は $19 \%$ と有意差を認めると報告してい $る^{8)}$. Hirschsprung 病の術前腸炎は, Hirschsprung 病の早期診断および早期手術により，その頻度およ び死亡例は経年的に著明に減少している ${ }^{9)}$. しかし, Hirschsprung 病で人工肛門を造設した Down 症候群が 腸炎を発症した時は, 急激な脱水を契機とした末梢循 環不全の発症を念頭において診療にあたることが重要 である. 特に, 肺血流増加型の心疾患のように体血管 血流量が不十分な病態では腸管循環が悪化し腸管蠕動 が低下することで, 劇症型腸炎の悪化が急速である可 能性が高いので十分に注意することが重要である ${ }^{10)}$.

$\frac{\text { 結 }}{\text { 論 }}$
先天性消化管閉塞症を合併した先天性心疾患に㧧
て, 基本的に消化管から介入し, 次に心疾患に介
する方針で生存率 $83 \%$ の結果が得られた. 染色体異

常・奇形症候群が半数あり，死亡例では $70 \%$ を占め た. 肺血流増加型の心疾患は循環動態のコントロール が付かない例や創傷治癒に影響する例があり，迅速な 対応が必要である. 胎児診断により予後の改善が期待 されるが，消化管疾患の胎児診断例が未だに少なく， 改善が必要である. 人工肚門の位置が後の心臓手術に 影響する場合があり，術前に多科による検討が必要で ある. Down 症候群の Hirschsprung 病, 人工肛門造 設例における劇症型腸炎は致死的となる得るため, 注 意が必要である.

\section{利益相反}

本研究に関連し，開示すべき利益相反（COI）関係にある企業 などはありません.

\section{著者役割}

平野恭悠, 江原英治は論文の構想, デザイン, データ集計扔よ び解釈, 論文原稿作成に関与した。

村上洋介, 中村香絵, 佐々木赳, 藤野光洋, 川崎有希, 西垣恭 一, 吉田葉子, 鈴木㖪敏は重要な知的内容に関わる批判的監查 に関与した。

\section{引用文献}

1）川田博昭：先天性心疾患を増悪させる小览外科疾患と その外科治療一治療時期と予後一。 日本外科学会雑誌 2011; 112: 25-230

2) Walker A, Stokes M, Moriarty A: Anesthesia for major general surgery in neonates with complex cardiac defects. Paediatr Anaesth 2009; 19: 119-125

3) Olgun $\mathrm{H}$, Karacan M, Caner I, et al: Congenital cardiac malformations in neonates with apparently isolated gastrointestinal malformations. Pediatr Int 2009; 51: 260-262

4) Spitz L: Esophageal atresia. Lessons I have learned in a 40-year experience. J Pediatr Surg 2006; 10: 1635-1640

5）村上 新：先天性心疾患を合併した小児外科疾患の治 療戦略一心臓外科医の立場から-。 日本外科学会雑誌 2011; 112: 235-239

6）麻生俊英：新生児外科治療成績に及ぼす心疾患の影響. 日本外科学会雑誌 2011; 112: 231-234

7) 池田恵一: 第 20 回日本小児外科学会会長講演ヒルシュ スプルング病の診断と治療一全国集計を中心として一. 日小外会誌 1983; 19: 803-819

8) Teitelbaum DH, Qualman SJ, Caniano DA: Hirschsprung disease identification of risk factors for enterocolitis. Ann Surg 1988; 207: 240-244

9) 水田祥代：Hirschsprung 病の診断と治療の変遷—-30 年 間の全国調査より一。 日本周産期・新生児医学会雑誌 2004; 40: 666-673

10) Hasserius J, Hedbys J, Graneli C, et al: Treatment and patient reported outcome in children with hirschsprung disease and concomitant congenital heart disease. BioMed Res Int 2017; 2017: 1703483 